\title{
Correction: Polygenic Risk Scores have high diagnostic capacity in ankylosing spondylitis
}

Li Z, Wu X, Leo PJ, et al. Polygenic Risk Scores have high diagnostic capacity in ankylosing spondylitis. Ann Rheum Dis 2021;80:1168-74.

An error occurred in figure 1. The key for the figure has swapped the colours of the lines for 'B27 status' and 'non-MHC GWS variants'. The numbers for these are given in the text but the figure is wrong and should be:
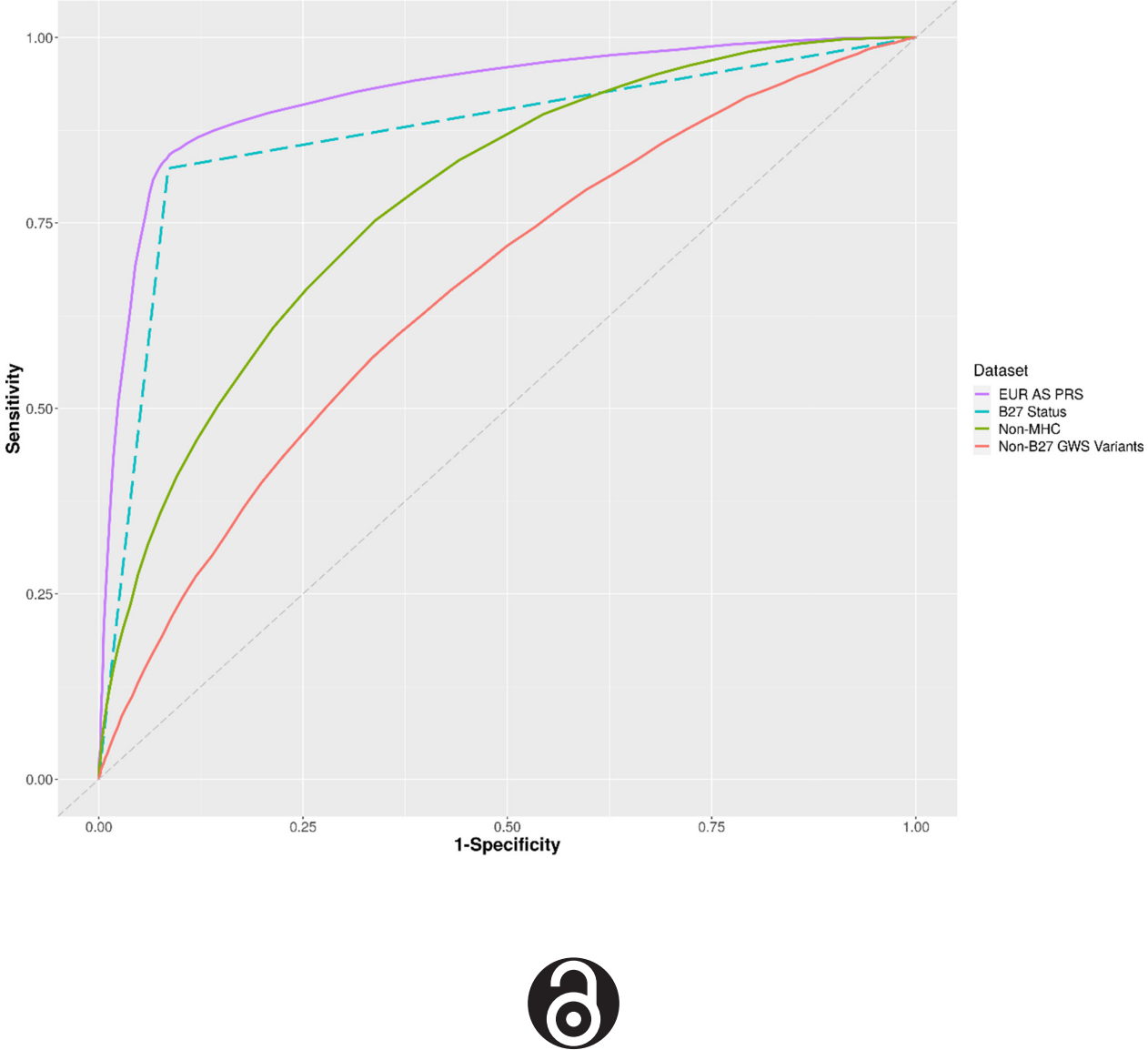

\section{OPEN ACCESS}

Open access This is an open access article distributed in accordance with the Creative Commons Attribution Non Commercial (CC BY-NC 4.0) license, which permits others to distribute, remix, adapt, build upon this work noncommercially, and license their derivative works on different terms, provided the original work is properly cited, appropriate credit is given, any changes made indicated, and the use is non-commercial. See: http://creativecommons.org/licenses/by-nc/ $4.0 \%$.

(C) Author(s) (or their employer(s)) 2021. Re-use permitted under CC BY-NC. No commercial re-use. See rights and permissions. Published by BMJ.

Ann Rheum Dis 2021;80:e187. doi:10.1136/annrheumdis-2020-219446corr1

D Check for updates 